\title{
Article \\ Enhancement of a Spent Irrigation Water Recycling Process: A Case Study in a Food Business
}

\author{
Guillermo Garcia-Garcia ${ }^{1,2, *(D)}$ and Sandeep Jagtap ${ }^{3, *(D)}$ \\ 1 Department of Chemical and Biological Engineering, The University of Sheffield, Sheffield S10 2TN, UK \\ 2 Department of Agrifood System Economics, Institute of Agricultural and Fisheries Research and \\ Training (IFAPA), P.O. Box 2027, 18080 Granada, Spain \\ 3 Sustainable Manufacturing Systems Centre, School of Aerospace, Transport and Manufacturing, \\ Cranfield University, Building 50, Cranfield MK43 0AL, UK \\ * Correspondence: G.Garcia-Garcia@sheffield.ac.uk or guillermo.garcia@juntadeandalucia.es (G.G.-G.); \\ S.Z.Jagtap@cranfield.ac.uk (S.J.)
}

Citation: Garcia-Garcia, G.; Jagtap, S. Enhancement of a Spent Irrigation Water Recycling Process: A Case Study in a Food Business. Appl. Sci. 2021, 11, 10355. https://doi.org/ 10.3390/app112110355

Academic Editors: Cristina Sousa Coutinho Calheiros and Ana Maria Antão-Geraldes

Received: 13 September 2021 Accepted: 2 November 2021 Published: 4 November 2021

Publisher's Note: MDPI stays neutral with regard to jurisdictional claims in published maps and institutional affiliations.

Copyright: (C) 2021 by the authors. Licensee MDPI, Basel, Switzerland. This article is an open access article distributed under the terms and conditions of the Creative Commons Attribution (CC BY) license (https:/ / creativecommons.org/licenses/by/ $4.0 /)$.

\begin{abstract}
Food operations use vast amounts of water. To reduce utility costs as well as concerns regarding water depletion in ecosystems, food businesses usually try to reuse their water. However, this often needs a recycling process to ensure the water is of good quality and safe to reuse in a food environment. This paper presents a case study of a grower of beansprouts and other varieties of sprouted seeds that uses six million litres of water weekly. Approximately $60 \%$ of their spent irrigation water is recycled using both $50 \mu \mathrm{m}$ and $20 \mu \mathrm{m}$ drum filtration. In addition, chlorine dioxide is used as part of the recycling process as a disinfectant. Our analysis demonstrated that the size of suspended solid particles in over $90 \%$ of the cumulative sample tested was smaller than the current $20 \mu \mathrm{m}$ filter in place, highlighting that the existing system was ineffective. We, then, explored options to enhance the water recycling system of the company. After careful analysis, it was proposed to install a membrane-filtration system with ultraviolet technology to increase the finest level of filtration from the existing $20 \mu \mathrm{m}$ to $0.45 \mu \mathrm{m}$ absolute and sterilize any remaining bacteria. This not only improved water quality, but also allowed for the removal of chemicals from the recycling system, delivering both financial and technical improvements.
\end{abstract}

Keywords: water; irrigation; food; sprouts; recycling; filtration; reverse osmosis; chlorine dioxide; chlorate; suspended solids

\section{Introduction}

Water is a key resource in the food sector, being paramount for crops, livestock, and cleaning processes. In fact, both water and food, along with energy, form the waterenergy-food security nexus, meaning that these three areas usually have an effect on each other [1,2]. Depletion of groundwater is often unsustainable at both regional and global scales [3]. Approximately 70\% of freshwater is currently used for crop irrigation [4].

Water use may be considerably minimized by water reuse [5,6]. However, improperly treated wastewater can contain high levels of foodborne pathogens. Particularly, spent irrigation water can potentially hold high microbial counts [7]. Therefore, advanced treatment processes are essential to eliminate any potential risks of reusing water [8]. Waterquality properties to consider include colour, dissolved oxygen, electrical conductivity, hardness, $\mathrm{pH}$, suspended solids, and turbidity [9].

There are several techniques to clean water. Filtration is a process where contaminants are removed from the water, reducing the volume of suspended solids and the turbidity of the water. Similarly, the concentration of microbes such as pathogens, viruses, and bacteria must also be reduced to a level that meets relevant legislative guidelines.

One form of a solids-removal system often used in water filtration is micro-screen drum filters. Water is filtered by gravity as it passes through drum screens, resulting 
in a high level of solids removal, whilst maintaining continuous filtration. An optimal micro-screen drum filter should be selected based on the particle-size distribution of the suspended solids in the water and the required water quality [10]. However, there is a limitation to the size of the filtration media that can be adopted due to the gravity feed nature of drum filtration.

Another process available to facilitate water filtration is the use of membranes. Membranes are barriers that allow for the selective permeation of different chemical species [11]. For the purpose of water reuse, membranes enable the separation of suspended and dissolved pollutants from water [12]. Membrane-separation processes have received increasing attention as advanced treatment alternatives for wastewater [13]. In 1957, the United States Public Health Service and the American Water Works Association used membranes for coliform bacteria recovery, resulting in the first major application of membrane technology in water treatment [14]. This led to the development and evolution of membrane separation processes that can remove materials of different sizes, such as microfiltration (MF), ultrafiltration (UF), and reverse osmosis (RO) [15]. These processes can be applied across a range of applications in various industries, including sea-water desalinization, medical and pharmaceutical processes, food operations, and industrial water reclamation. Thanks to the broad range of treatment options, different water quality levels can be achieved depending on the intended use of the reclaimed water.

Membrane separation processes are widely used methods within crop irrigation systems. The basic properties of membranes make them ideal for industrial applications, as they are simple in both concept and operation and operate in mild conditions $[11,16]$. They are also low in energy consumption and cheap. In addition, MF and UF are efficient methods for the final clean-up of secondary effluents [11], and combined MF/RO systems can significantly reduce levels of viable bacteria passing to the RO units [17].

$\mathrm{RO}$ is a pressure-driven membrane process based on the preferential transport of water through a dense separation layer of a membrane [18]. The RO process is dissimilar to regular filtration because it is not based on filter size. Weintraub (2001) suggested that in $\mathrm{RO}$, unlike in filtration, it is not membrane pore size nor dissolved particle size that determine the success of the separation process [19]. Roseman (2003) claimed that RO could support plant growth with less variability, as the water quality is constant and free from impurities [20].

There is, however, an argument that $\mathrm{RO}$ removes useful components from the water. Kozisek (2008) highlighted that RO removes both harmful contaminants present in the water as well as some desirable minerals [21]. RO generally removes salt, manganese, iron, fluoride, lead, and calcium [22]. This raises the issue that for the purpose of growing crops, desirable nutrients would be required to be added back into the treated water, adding additional processes, materials, and therefore, costs. Another drawback of $\mathrm{RO}$ is that the process wastes between 3 and $4 \mathrm{~L}$ of water for every litre purified [20,23].

Furthermore, although RO does remove some bacteria, it may not remove all bacteria [24]. KK Water Purification Ltd. (2019) claims that RO alone is not recognized as an exhaustive barrier to microbiological contamination [23]. Since RO has the highest level of suspended-solid removal of all the membrane technologies, regardless of the membrane filtration process adopted, a further process is required to achieve the best results in water cleaning.

Chlorine dioxide is commonly used to disinfect water. The chlorine dioxide used in these applications is commonly generated onsite, usually from sodium chlorite mixed with hydrochloric acid in chlorine dioxide generators. Removal of chlorine dioxide from the water treatment process not only removes the risk of harmful chemical by-products such as chlorates being created but also removes a particular health and safety risk. However, chlorine dioxide is a reactive gas that may affect human health and is explosive at concentrations above $10 \% v / v$ in the air [25].

Ultraviolet (UV) technology has been successfully used for the control of pathogen microorganisms, with the most common application for UV light in water treatment 
systems being disinfection. UV successfully attacks chlorine-resistant microorganisms by disinfecting water as it flows through a chamber containing a UV lamp. As the water flows past the lamp, microorganisms receive a lethal dose of UV light. UV water disinfection is, therefore, a safe, chemical-free way to treat water [23].

In this context, the purpose of this article is to assess the current spent irrigation water recycling process used in a food business, to then, propose a solution to improve the filtration system and, consequently, remove the requirement to treat the spent irrigation water with chemicals.

\section{Methods}

This section explains the context of the case study, the main objectives identified, and the different solutions explored.

\subsection{Context}

The company selected for the case study is a food business located in central England. It grows beansprouts and other sprouted seeds and uses more than 6 million litres of recycled water weekly. Spent irrigation water is first filtered through a $20 \mu \mathrm{m}$ drum filter to remove suspended solids. The water is, then, treated with chlorine and citric acid to balance the $\mathrm{pH}$. Chlorine dioxide is, then, used as part of the microbial disinfection process. However, these processes only allow the business to recycle in the region of $50-60 \%$ of the spent irrigation water daily, with the remainder being disposed of as waste to effluent. This disposal means that potable mains water must be introduced into the process to replenish the volume disposed of.

The challenge facing the business is to recycle a significant amount of water, whilst remaining compliant with EU legislation regarding water quality. The European Sprouted Seed Association (2016) details that in order to comply with Commission Regulation (EU) No 210/2013 on the approval of establishments producing sprouts pursuant to Regulation (EC) No 852/2004, "through all steps of the production process, water that comes into contact with seeds or sprouts should be water meeting the microbiological requirements of potable water listed in Council Directive 98/83/EC, Annex I, part A" [26]. This is supported by Section 13 of EU Regulation 209/2013 as regards the microbiological criteria for sprouts [ ... ] that details that "food business operators producing sprouts should therefore comply with the food safety criteria for ready-to-eat food laid down in Union legislation" [27]. Section 11 of the same regulation says that "testing of spent irrigation water for pathogenic bacteria has been proposed as an effective indicator of the types of micro-organisms present in the sprouts".

The company manages this process and pathogen risk by treating the spent irrigation water with chlorine dioxide to reduce microbial levels within the water. Due to potential changes to EU legislation, the use of chlorine dioxide as a decontamination step is now under review.

In 2015, the European Food Safety Authority was directed by the European Commission to conduct a review of chlorate levels. The review concluded that there were potential risks associated with chlorates in food products and made recommendations for future limits [28]. Following this study, the European Commission tabled a proposed amendment to Annex III to Regulation (EC) No 396/2005 of the European Parliament and the Council regarding maximum residue levels for chlorate in or on certain products [29]. The recommendations made were that the maximum residue limits (MRLs) for section 0251000, i.e., "Lettuces and salad plants", a sub section of 0250000 "Leaf vegetables, herbs and edible flowers", should be set at 0.15. Products that fall under the "Lettuces and salad plant" category and are also governed by the 0.15 limit are lamb's lettuces/corn salads, lettuces, escaroles/broad-leaved endives, cresses and other sprouts and shoots, land cresses, roman rocket/rucola, red mustard, baby leaf crops (including brassica species), and others. Beansprouts and sprouted seeds are categorized under 0251040 "Cresses and other sprouts and shoots". 
Previous analysis undertaken in the company found that beansprout products on the open market have MRL chlorite levels well in excess of the proposed limits. The Agriculture and Horticulture Development Board claimed that chlorate exceedance is most likely to arise from chlorine dioxide or other chlorinated water used for crop irrigation [30]. Furthermore, although chlorine disinfection of waste process water is widespread, it recently came under criticism due to toxicity concerns [31]. This suggests that if the business is to remain compliant with amended legislation, an alternative water treatment process may be soon required.

\subsection{Project Planning}

In order to explore solutions to this issue, an initial project group was established with key stakeholders from production, technical, and engineering functions. This was to ensure that the key requirements involved in changing the existing water recycling process were established. A group project planning meeting was held so that all stakeholders had input into the project charter and were clear on the aims of the project, namely, to deliver an improved level of filtration, whilst still delivering the required technical standards and doing so to deliver a financial benefit to the business.

As a result of the meeting, it was determined that, in order to improve the process, it was key to first establish the current water quality in terms of suspended solids. It was also crucial to evaluate any available options for improvement that would deliver a required payback. It was also decided to outsource this work to companies that have the equipment to conduct the testing to the required level.

The project team formulated and agreed on the project Gantt chart (Figure 1) in order to provide a clear plan of timescales and responsibilities to deliver the project to schedule. Project timescales were agreed based on realistic expectations for gaining capital approval and the anticipated lead times for delivery and installation. In addition, consideration was given to impact upon operations when planning the project.

\begin{tabular}{|c|c|c|c|c|c|c|c|c|c|c|c|c|c|c|c|c|c|c|c|c|c|c|c|}
\hline \multirow{2}{*}{\multicolumn{24}{|c|}{$\begin{array}{l}\text { Activity / working day } \\
\text { Conduct research to determine requirements }\end{array}$}} \\
\hline & & & & & & & & & & & & & & & & & & & & & & & \\
\hline \multicolumn{23}{|c|}{ Hold meeting with central technical stakeholders } & \\
\hline \multicolumn{24}{|c|}{ Invite companies to provide quotations } \\
\hline \multicolumn{24}{|c|}{ Collate quotations } \\
\hline \multicolumn{24}{|c|}{ Hold meeting to review quotations and determine suitability } \\
\hline \multicolumn{24}{|c|}{ Write capital proposal } \\
\hline \multicolumn{24}{|l|}{ Submit capital proposal } \\
\hline \multicolumn{24}{|l|}{ Await capital proposal decision } \\
\hline \multicolumn{24}{|l|}{ Place order } \\
\hline \multicolumn{24}{|l|}{ Make initial payment } \\
\hline \multicolumn{24}{|l|}{ Delivery } \\
\hline \multicolumn{24}{|l|}{ Pipework preparation } \\
\hline \multicolumn{24}{|l|}{ Disconnect and remove existing filter } \\
\hline \multicolumn{24}{|c|}{ Connect new filter } \\
\hline \multicolumn{24}{|l|}{ Commission and test } \\
\hline \multicolumn{24}{|l|}{ Validate water quality } \\
\hline \multicolumn{24}{|l|}{ Make final payment } \\
\hline \multicolumn{24}{|l|}{ Post-installation review meeting } \\
\hline Sign off project as complete & & & & & & & & & & & & & & & & & & & & & & & \\
\hline
\end{tabular}

Figure 1. Project Gantt chart.

\subsection{Project Payback}

One of the key objectives established in the project planning meeting was to ensure that the project was self-funded within the required 24-month payback period for capital expenditure. Consequently, different areas of savings for the company were explored.

One of the main project aims was to remove chemical treatment from the spent irrigation water recycling process. The site engineering team conducted a full review of all plants associated with the recycling system, with the view of highlighting areas that 
would become redundant if the need for chemicals was removed. The cost of chemicals used for the treatment of spent irrigation water was GBP 45,000 pa. Additionally, three pumps with a combined rating of $20 \mathrm{kWh}$ would become redundant. With an associated cost provided by the accounts department of GBP 0.07213 per $\mathrm{kWh}$, this would deliver an annualized saving of around GBP 12,000. In conclusion, GBP 114,000 expenditure was allowed to deliver an adequate return on investment (ROI).

\subsection{Presentation of Potential Solutions}

In order to carry out the suggested testing and propose solutions, three companies were invited to submit quotations:

- Company 1-the current supplier of RO filtration at the main company site;

- Company 2-an external company with no previous affiliation to act as an independent control;

- Company 3-the manufacturer of the existing drum filter technology.

Following initial meetings with Company 1 , it was clear that in order to install an RO plant, the company would require a basic budget price upwards of GBP 1,000,000.

Company 2 is a supplier of membrane filtration systems and, as such, does not conduct water analysis; however, in order to determine the optimum filtration for the process, they work with a third-party company to provide water analysis. Samples of untreated spent irrigation water were collected and sent for analysis to determine levels of suspended solids in the water. Water flow rates were also assessed in order to determine the size of the filtration unit required. This was carried out by reviewing the maximum number of process irrigations per hour multiplied by the volume of water per irrigation. It was determined that there was a maximum of four process irrigations per hour, each at a maximum of $15 \mathrm{~m}^{3}$, delivering a requirement to process a maximum of $60 \mathrm{~m}^{3} / \mathrm{h}$.

Company 3 supplies drum filtration systems. The existing drum filtration system was reviewed to consider whether improving or replacing the system would be adequate.

\section{Results}

This section presents the results of the initial water analysis, an analysis of the potential solutions, a description of the implementation of the solution selected, and reflections on the final results of the project.

\subsection{Water Analysis Results}

Samples were collected in February 2019. Two hundred and fifty-six bins of size $0.4 \mu \mathrm{m}$ to $81.51 \mu \mathrm{m}$ were used. The volume of the samples was $3 \mathrm{~mL}$, the electrolyte volume was $200 \mathrm{~mL}$, and the analytic volume was $10,000 \mu \mathrm{L}$. The electrolyte used was BCI ISOTON II. The aperture diameters used in the test were 280,50 , and $20 \mu \mathrm{m}$. The total count was 3,156,170. The main results of the untreated water analysis are shown in Figures 2 and 3. Statistics results are shown in Table 1.

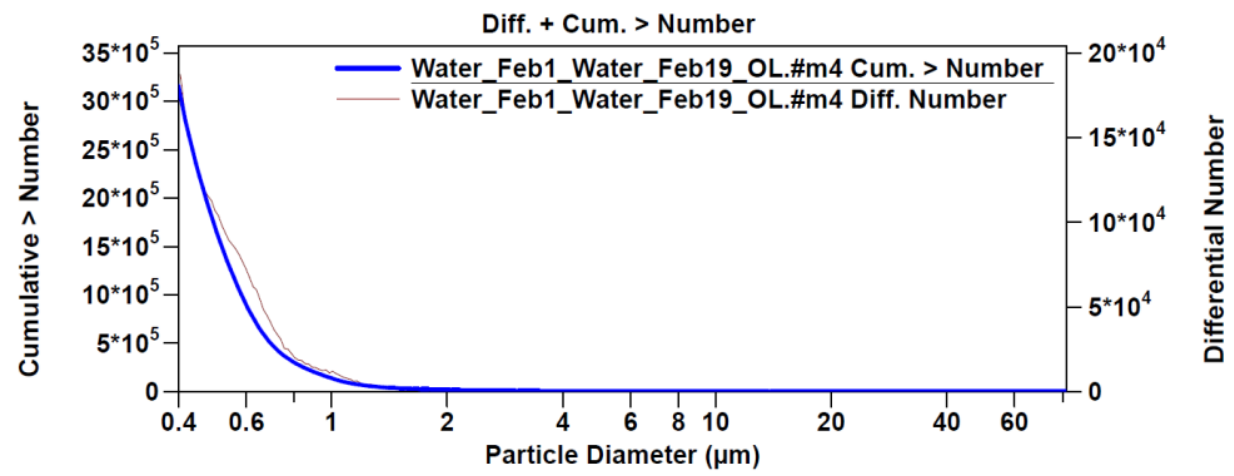

Figure 2. Cumulative number of particles in comparison to particle diameter. 


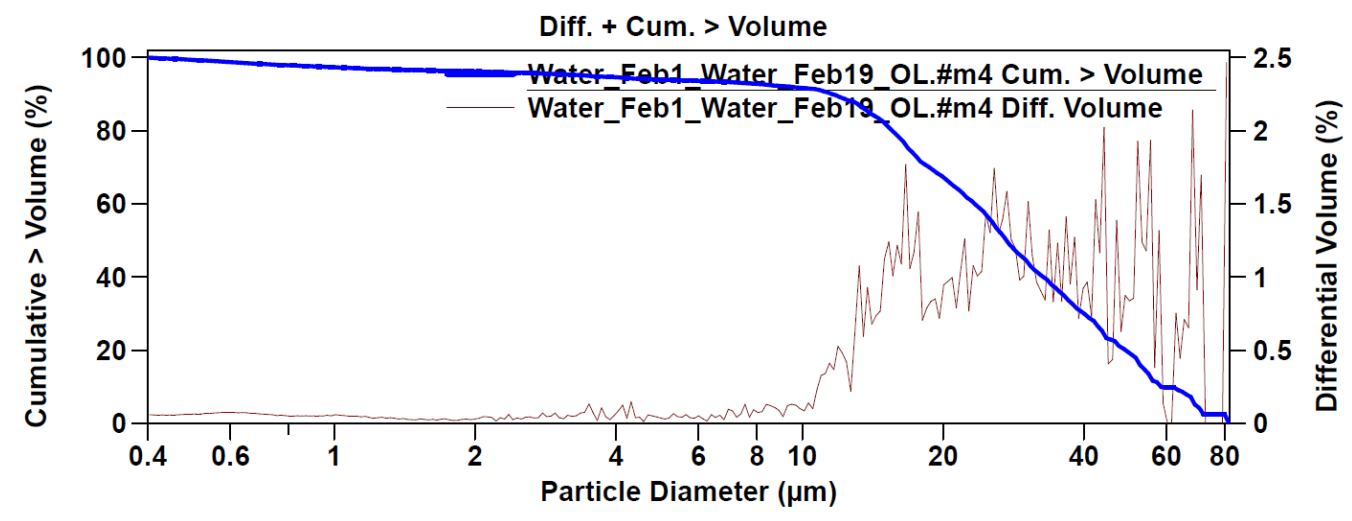

Figure 3. Particle diameter in relation to cumulative volume.

Table 1. Statistical data of the tests. All values in $\mu \mathrm{m}$.

\begin{tabular}{ccc}
\hline & Number & Volume \\
\hline Mean & 0.591 & 31.67 \\
Median & 0.510 & 27.33 \\
Mode & 0.404 & 80.67 \\
$95 \%$ confidence limits & $0.591-0.592$ & $31.65-31.69$ \\
SD & 0.55 & 19.2 \\
$\mathrm{~d}_{10}$ & 0.415 & 11.62 \\
$\mathrm{~d}_{50}$ & 0.510 & 27.33 \\
$\mathrm{~d}_{90}$ & 0.789 & 58.38 \\
\hline
\end{tabular}

The results in Figure 2 show the cumulative number of particles when compared to particle diameter. The total number of particles counted was $3156 * 10^{3}$. Of these, $96 \%$ were smaller in diameter than $1 \mu \mathrm{m}$, with less than $1 \%$ of the overall cumulative volume being larger than $20 \mu \mathrm{m}$ in diameter.

Interpreting the data shown in Figure 3, it is apparent that in over $90 \%$ of the cumulative volume of water tested, the level of suspended solid particles falls within the $<10 \mu \mathrm{m}$ particle size, with the remainder of the solids ranging from 11 to $80 \mu \mathrm{m}$. The results demonstrate that in order to make any improvement to the existing water quality, there is a requirement to filter solids to a level of $<10 \mu \mathrm{m}$. Further interpretation of the analysis results highlights that $17.6 \%$ of the overall sample had a level of suspended solids with a particle size of $<1 \mu \mathrm{m}$.

\subsection{Analysis of Potential Solutions}

Based on the results reported above, the three companies that were approached initially were requested to provide suggested solutions and associated quotations.

Company 1 suggested that, to implement an RO-based system, a minimum of GBP $1,000,000$ would be required. No quotation was submitted, as it was clear that this was not a viable option in terms of ROI. Upon reflection, more research should have been conducted on the estimated costs involved with RO technology before this was considered.

Company 2 supplied a proposal to supply and fit a membrane filtration system, delivering nominal filtration from 3 to $0.45 \mu \mathrm{m}$. A subsequent in-line filter would also be installed in order to deliver absolute filtration to $0.45 \mu \mathrm{m}$. Two UV sterilization systems would also be added to facilitate the sterilization of any bacteria smaller than $0.45 \mu \mathrm{m}$. The total cost for this proposal was GBP 90,000.

Company 3 supplied a proposal to supply and fit a triplex drum filtration system delivering a nominal $5 \mu \mathrm{m}$ filtration. This would include two duty units, and a third unit to come on line when one of the first two is on auto backwash. Their capacity is $34 \mathrm{~m}^{3} / \mathrm{h}$ per unit. There was a secondary recommendation to fit a subsequent centrifugal 
cartridge system required to deliver nominal $1 \mu \mathrm{m}$. This would include two duty units with a capacity of $34 \mathrm{~m}^{3} / \mathrm{h}$ per unit. The total cost of this proposal was GBP 29,000.

Upon analysis of the proposals, both the membrane and the drum proposal deliver improved water filtration to a higher grade than the existing $20 \mu \mathrm{m}$. In order to fulfil the aim of removing chemical treatment from the water, it was key to understand the level of filtration required to remove bacteria and pathogens to a level where the water could be deemed "potable". Filtration to $1 \mu \mathrm{m}$ is a vast improvement on the existing process in terms of particle removal. However, this filtration would not yet remove the majority of the bacteria from the water. It has been claimed that filters with an absolute minimum rating of $0.48 \mu \mathrm{m}$ are required to strain out the smallest bacteria [32]. Furthermore, it was calculated that this filtration would only remove $83 \%$ of the suspended solids. Based on this, the proposal from Company 3 to install a $5 \mu \mathrm{m}$ drum filter with an additional nominal $1 \mu \mathrm{m}$ unit would not allow the removal of the chemical treatment.

Therefore, the proposal by Company 2 to install a membrane filtration system with nominal filtration to $0.45 \mu \mathrm{m}$, with a subsequent in-line filter and UV sterilisation system, seemed to be the ideal solution and was selected. A scheme of this system is shown in Figure 4. It should be noted that, with the new system, fresh water and wastewater flows could be reduced to virtually zero. For the membrane filtration system, the vessel diameter is $1.2 \mathrm{~m}$, and the filtration flow range is $28-68 \mathrm{~m}^{3} / \mathrm{h}$. The addition of an absolute "safeguard" filter following the primary filtration system would ensure that absolute filtration of $0.45 \mu \mathrm{m}$ is achieved. This secondary filtration system allows for flow rates of $50 \mathrm{~m}^{3} / \mathrm{h}$. The downside of this is the use of filter cartridges, which are consumable items that require a certain amount of ongoing replacement, adding additional overhead back into the business. This system houses 11 cartridges.

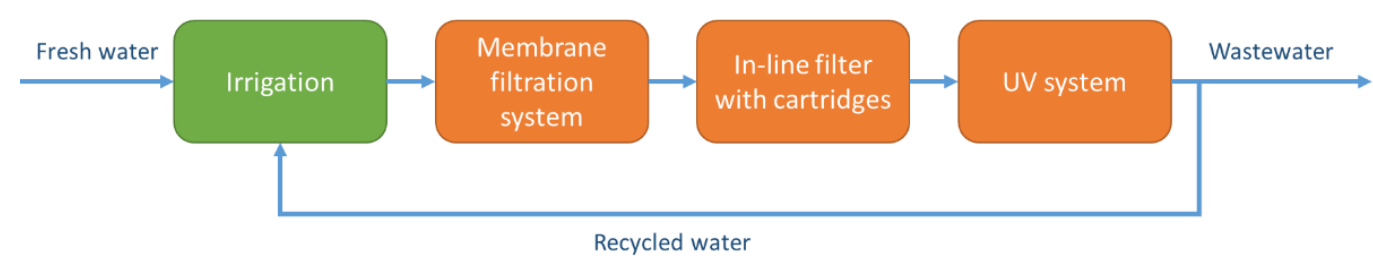

Figure 4. Scheme of the solution applied. In orange, the new system installed; in green, the irrigation process; blue arrows, water flows.

MF membranes are efficient at removing bacteria and fine inorganic particles, but they do not remove colloids and all viruses [33,34]. Company 2's proposal also included the addition of UV post-membrane sterilisation, which adds an additional step in reducing the risk of the presence of harmful components in water. A combination of absolute filtration and UV would allow for removing the chemical treatment from the process. The UV system houses two UV ECO-Light E130 lamps, consumes $0.32 \mathrm{~kW}$, and allows for a maximum pressure of 10 bar.

A set requirement of the project was to deliver an ROI period of 24 months or less. The ROI was predominately based on facilitating the removal of the requirement for chemicals from the treatment process, as this had a potential saving of GBP 90,000 over the 24-month period, and the removal of three pumps, saving GBP 24,000 over the 24-month period. The costs of each solution, as well as the current practice, is broken down in Table 2.

The proposed drum filter replacement from Company 3 is the cheapest of the two proposals at GBP 29,000. However, this solution would not facilitate the total removal of the chemical from the process, so the GBP 90,000 saving from chemical removal is not achieved. It only delivers the GBP 24,000 saving from the pump removal, which is not enough ROI to deliver the project objective. 
Table 2. Costs associated with the current practice and the solutions offered by each company.

\begin{tabular}{|c|c|c|c|c|c|c|c|c|}
\hline \multirow[b]{2}{*}{ Installation costs, GBP } & \multicolumn{2}{|c|}{ Current Practice } & \multicolumn{2}{|c|}{ Solution 1} & \multicolumn{2}{|c|}{ Solution 2} & \multicolumn{2}{|c|}{ Solution 3} \\
\hline & & & Reverse osmosis & $1,000,000$ & Filtration + UV & 90,000 & $\begin{array}{l}\text { Triplex drum } \\
\text { filtration }\end{array}$ & 29,000 \\
\hline \multirow{2}{*}{ Cost, GBP/year } & Chemicals & 45,000 & & & Cartridges & 5940 & Chemicals & 45,000 \\
\hline & Pumps & 12,000 & & & & & & \\
\hline $\begin{array}{l}\text { Cost, GBP/payback } \\
\text { period }\end{array}$ & & 114,000 & & $1,000,000$ & & 101,880 & & 119,000 \\
\hline $\begin{array}{l}\text { Saving, GBP/payback } \\
\text { period }\end{array}$ & & 0 & & $-886,000$ & & 12,120 & & -5000 \\
\hline
\end{tabular}

The proposed membrane filtration from Company 2 with the additional UV sterilisation is the most expensive of the two remaining options at GBP 90,000. The increased level of filtration does allow for the removal of chemicals from the treatment process and also allows for the removal of the redundant pumps. However, there is an additional ongoing cost for absolute filtration cartridge replacement. The manufacturers confirmed that, with the $0.45 \mu \mathrm{m}$ nominal self-cleaning filter in place, this would have an efficiency of around $2 \mu \mathrm{m}$ at $99 \%$, increasing the on-stream life by at least $100 \%$, effectively resulting in the lifespan of any consumable cartridges being extended by the same amount. The expected lifespan of the absolute cartridges is 6-8 weeks, with a replacement cost of GBP 990, generating an annual overhead consumables cost of GBP 5940. This is a cost that can be picked up by the site budget separately from any capital request. In summary, Company 2's proposal provides an ROI of GBP 4750 per month, resulting in a 19-month payback period, saving a total of GBP 12,120 in the 24-month period considered.

An additional benefit that the adoption of this system delivers is a reduction in mains water usage. A reduction in mains water demand causes a reduction in the maximum daily demand (MDD) charge levied on the business, resulting in lower utility costs. Furthermore, if the spent irrigation water is filtered and treated to a higher grade than in the existing system, this may reduce the amount of this water that is sent offsite to effluent.

\subsection{Project Implementation and Delivery}

The final consideration in the planning stage was the facilitation of maintaining operations during any transition period, while the existing recycling system was replaced.

Due to the modular nature of the pipework and process within the recycling operation, any replacement system could be installed alongside the existing process and could be connected once installed, resulting in a minimal amount of process downtime. For the period that the system was offline, there was enough capacity within the mains water supply and onsite storage to allow the growing operation to continue to run unaffected without the requirement to use recycled water. This would incur an additional cost that could be absorbed within the project capital plan.

Relevant safety requirements regarding the collection of samples from open underground sump pits were adhered to. The area was cordoned off with temporary barriers, and all samples were collected by a trained site engineer attached to a harness. The engineer was wearing appropriate personal protective equipment (PPE) for the task to ensure that he did not come into contact with water that had not been either filtered or chemically cleaned, minimizing exposure to the slight risk of any pathogens present.

Due to the higher grade of filtration offered by the membrane technology, the quality of any treated process water is of a higher quality than that delivered by the existing drum filtration onsite. As such, it is not anticipated that there will be any safety risks posed to either employees or food products as a result of this project. 


\subsection{Reflections following the Project Completion}

The project achieved the objective set to enable water reuse for irrigation and remove the need of using chemicals to treat water. The membrane filtration system with the in-line filter deliver absolute filtration to $0.45 \mu \mathrm{m}$. This removes most bacteria and suspended solids. The UV system allows for sterilising the smallest remaining bacteria. The businesses can now increase their recycling rate for spent irrigation water from the previous $50-60 \%$ to $100 \%$, both reducing water use and water sent to effluent by $40-50 \%$. This, together with the GBP 12,120 savings in 2 years offered by the removal of the chemicals and use of pumps, gives an important economic saving to the company, making the project economic and environmentally sustainable. Furthermore, the business is now compliant with a potential EU maximum residue limits for chlorate.

Initial stages of the project, which relied solely on activities conducted by the stakeholder team, adhered to the schedule and were completed in time in full. The main challenge came when external factors, such as capital approval, did not proceed as expected. Although the process was expected to take a period of six weeks, it was extended far beyond this due to factors out of the control of the project team. This subsequently delayed the entire project.

In hindsight, it may have been beneficial to split the project into two distinct sections, each with its own Gantt chart. The first chart would run-up to the point of submitting the capital request, with a subsequent chart created by the stakeholder group once financial approval had been granted. Additionally, the heads of operations and finance should have been included in the stakeholder meeting so that a clearer indication of available financial options could be determined. This would have allowed the project team to generate a more realistic project plan and the project manager to manage the expectations of the third-party businesses that worked alongside on the project.

\section{Conclusions}

This project aimed to enhance the water recycling process in a food company with a view to improve the quality of the spent irrigation water. Water analysis demonstrated that the existing level of filtration was ineffective, as the suspended-solid particle size was considerably smaller than the existing $20 \mu \mathrm{m}$ drum filter.

Three options were considered: reverse osmosis (RO), an alternative drum filtration system, and a membrane filtration system. RO would deliver extremely high-quality water. However, the water required for irrigations needs to retain key nutrients that are likely to be removed during the $\mathrm{RO}$ process. Furthermore, the cost of the RO system was deemed prohibitive.

The proposal to improve the drum filtration to $1 \mu \mathrm{m}$ is the cheapest option and delivers a return on investment. However, the results of the water analysis demonstrated that $1 \mu \mathrm{m}$ does not remove enough suspended solids and bacteria. This does not allow for the removal of a chemical treatment due to the risk of bacteria still being present in the water.

A membrane filtration system filtering a nominal $0.45-3 \mu \mathrm{m}$ delivers the required level of filtration. The addition of an absolute $0.45 \mu \mathrm{m}$ filter after the nominal guarantees that $0.45 \mu \mathrm{m}$ filtration is achieved. In addition, an inline UV filter effectively sterilizes any remaining bacteria smaller than $0.45 \mu \mathrm{m}$. This allows for the removal of the existing chemical treatment.

Facilitating the removal of chemicals from the process, whilst still delivering water that meets the microbiological criteria relating to spent irrigation water, results in the aims of the project being fulfilled. The removal of chemicals provides an overall saving to the business that meets the requirement to provide a return on investment within 24 months. Crucially, removing chemicals from the treatment process also eradicates the effect that chlorine dioxide has on the residue chlorate levels in the grown beansprouts. This means that if the proposed EU maximum residue limits (MRLs) become law, the business would already be compliant. Compliance with these MRLs would potentially give the business a 
competitive advantage over other growers if they have not taken similar remedial actions. This could potentially become a unique selling point.

In conclusion, reducing water use and preserving water quality is particularly important in the food sector. This study shows how different solutions can be applied to optimize water management in food businesses, both improving the quality of the water reused and minimizing the use of fresh water.

Author Contributions: Conceptualization, S.J.; methodology, S.J.; validation, G.G.-G. and S.J.; formal analysis, G.G.-G.; resources, S.J.; data curation, G.G.-G.; writing-original draft preparation, G.G.-G.; writing—review and editing, G.G.-G.; supervision, S.J.; project administration, S.J. All authors have read and agreed to the published version of the manuscript.

Funding: Guillermo Garcia-Garcia acknowledges the Grant Juan de la Cierva Incorporación funded by MCIN/AEI/10.13039/501100011033.

Institutional Review Board Statement: Not applicable.

Informed Consent Statement: Not applicable.

Data Availability Statement: Not applicable.

Acknowledgments: We would like to acknowledge staff from the company that participated in the case study as well as from the three anonymized companies who provided data and ideas for the successful completion of this project.

Conflicts of Interest: The authors declare no conflict of interest.

\section{References}

1. Food and Agriculture Organization of the United Nations. The Water-Energy-Food Nexus. A New Approach in Support of Food Security and Sustainable Agriculture; Food and Agriculture Organization: Rome, Italia, 2014. Available online: http:/ /www.fao. $\mathrm{org} / 3 / \mathrm{bl}$ 496e/bl496e.pdf (accessed on 19 October 2021).

2. Jagtap, S.; Garcia-Garcia, G.; Rahimifard, S. Optimisation of the resource efficiency of food manufacturing via the Internet of Things. Comput. Ind. 2021, 127, 1033397. [CrossRef]

3. Gleeson, T.; Wada, Y.; Blerkens, M.F.P.; van Beek, L.P.H. Water balance of global aquifers revealed by ground water footprint. Nature 2012, 488, 197-200. [CrossRef] [PubMed]

4. Zimmerman, J.B.; Mihelaic, J.R.; Smith, J. Global stressors on water quality and quantity. Environ. Sci. Technol. 2008, 42, 4247-4254. [CrossRef] [PubMed]

5. Casani, S.; Rouhany, M.; Knøchel, S. A discussion paper on challenges and limitations to water reuse and hygiene in the food industry. Water Res. 2005, 39, 1147. [CrossRef] [PubMed]

6. Jagtap, S.; Skouteris, G.; Choudhari, V.; Rahimifard, S.; Duong, L.N.K. An Internet of Things Approach for Water Efficiency: A Case Study of the Beverage Factory. Sustainability 2021, 13, 3343. [CrossRef]

7. Steele, M.; Odumeru, J. Irrigation water as a source of foodborne pathogens on fruits \& vegetables. J. Food Prot. 2004, 67, 2839-2849. [PubMed]

8. Chekli, L.; Kim, J.; El Saliby, I.; Kim, Y.; Phuntsho, S.; Li, S.; Ghaffour, N.; Leiknes, T.; Shon, H. Fertilizer drawn forward osmosis process for sustainable water reuse to grow hydroponic lettuce using commercial nutrient solution. Sep. Purif. Technol. 2017, 181, 18-28. [CrossRef]

9. Perlman, H. Water Properties: Dissolved Oxygen. U.S. Geological Survey. 2016. Available online: https://www.usgs.gov / special-topic / water-science-school/science / dissolved-oxygen-and-water?qt-science_center_objects=0\#qt-science_center_ objects (accessed on 13 March 2020).

10. Dolan, E.; Murphy, N.; O'Heir, M. Factors influencing optimal micro-screen drum filter selection for recirculating aquaculture systems. Aquac. Eng. 2013, 56, 42-50. [CrossRef]

11. Terrell, J. Water Filtration Systems: Processes, Uses and Importance; Nova Science Publishers, Inc.: New York, NY, USA, 2016.

12. Judd, S.; Jefferson, B. Membranes for Industrial Wastewater Recovery and Re-Use; Elsevier Science: Kidlington, UK, 2003.

13. Ottoson, J.; Hansen, A.; Björlenius, B.; Norder, H.; Stenström, T.A. Removal of viruses, parasitic protozoa and microbial indicators in conventional and membrane processes in a wastewater pilot plant. Water Res. 2006, 40, 1149-1457. [CrossRef] [PubMed]

14. Porter, M.C. Microfiltration. In Synthetic Membranes: Science, Engineering and Applications; Bungay, P.M., Lonsdale, H.K., de Pinho, M.N., Eds.; NATO ASI Series: Boston, MA, USA, 1983; pp. 225-247.

15. Madaeni, S.S. The application of membrane technology for water disinfection. Water Res. 2009, 33, 301-308. [CrossRef]

16. Saltik, B.; Ozkan, L.; Jacobs, M.; Van de Padt, A. Optimal Start-Up and Operation Policy for an Ultrafiltration Membrane Unit in Whey Separation. Comput. Aided Chem. Engl. 2016, 38, 1599-1604. 
17. Ghayeni, S.B.; Madaeni, S.S.; Fane, A.G.; Schneider, R.P. Aspects of microfiltration and municipal wastewater use. Desalination 1995, 106, 25-29. [CrossRef]

18. Grabowski, A. Electromembrane Desalination Processes for Production of Low Conductivity Water; Logos Verlag Berlin GmbH: Berlin, Germany, 2010.

19. Weintraub, B. Sidney Loeb. Co-Inventor of Practical Reverse Osmosis; The Negev Academic College of Engineering: Beer-Sheva, Israel, 2001.

20. Roseman, J. Grower 101: Reverse Osmosis-The Pros and Cons. Greenhouse Product News. 2003. Available online: https://gpnmag. com/article/grower-101-reverse-osmosis-pros-and-cons/ (accessed on 14 December 2019).

21. Kozisek, F. Health Risks from Drinking Demineralised Water National Institute of Public Health Czech Republic. 2008 Available online: https://www.who.int/water_sanitation_health/dwq/nutrientschap12.pdf (accessed on 11 May 2020).

22. Binnie, C.; Kimber, M.; Smethhurst, G. Basic Water Treatment, 3rd ed.; Thomas Telford Ltd.: London, UK, 2002.

23. KK Water Purification LTD. UV Water Treatment. 2019. Available online: http://www.kkwater.com/uv-water-treatment (accessed on 15 May 2020).

24. Wood, P. What Does Reverse Osmosis Remove from Water and Will It Remove Bacteria? The Industrial Water Purification Blog. 2016. Available online: https:/ /blog.wychwood-water.com/what-does-reverse-osmosis-remove-from-water-and-willit-remove-bacteria. (accessed on 11 September 2019).

25. Dobson, S.; Cary, R. Chlorine Dioxide (Gas). Concise International Chemical Assessment Document 37, World Health Organization. Geneva. 2002. Available online: https://www.who.int/ipcs/publications/cicad/en/cicad37.pdf (accessed on 3 February 2020).

26. European Sprouted Seed Association. ESSA Hygiene Guideline for the Production of Sprouts and Seeds for Sprouting. 2016. Available online: https:/ / ec.europa.eu/food/sites/food/files/safety/docs/biosafety_fh_guidance_essa_sprouts-and-seeds_ en.pdf (accessed on 11 September 2019).

27. European Commission. Commission Regulation (EU) No 209/2013 of 11 March 2013 Amending Regulation (EC) No 2073/2005 as Regards Microbiological Criteria for Sprouts and the Sampling Rules for Poultry Carcases and Fresh Poultry Meat. Available online: https:/ / eur-lex.europa.eu/legal-content/EN/TXT/?uri=CELEX\%3A32013R0209 (accessed on 26 February 2020).

28. European Food Safety Authority. Risks for public health related to the presence of chlorate in food. EFSA Panel on Contaminants in the Food Chain (CONTAM). EFSA J. 2015, 13, 4135. Available online: https:/ / efsa.onlinelibrary.wiley.com/doi/pdf/10.2903/j. efsa.2015 (accessed on 23 March 2020).

29. European Commission. Commission Regulation (EU) 2020/749 Amending Annex III to Regulation (EC) No $396 / 2005$ of the European Parliament and of the Council as Regards Maximum Residue Levels for Chlorate in or on Certain Products. Available online: http:/ / www.iib.org.tr/files/downloads/PageFiles/\%7B3b762c80-.ec79-4cae-b5ea-87a2e5ef94a8\%7D/Files / Ek-1_yonetmelik_taslagi.pdf (accessed on 4 March 2020).

30. AHDB. Chlorine and Its Oxides: Chlorate and Perchlorate Review. 2016. Available online: https://horticulture.ahdb.org.uk/ sites/default/files/research_papers/CP\%20154a_Report_Final_2016.pdf (accessed on 4 September 2019).

31. Harveston, K. How Does Water Treatment in the Food and Beverage Industry Work? New Food. July 2019. Available online: https:/ / www.newfoodmagazine.com/article/89676/water-treatment-industry-work/ (accessed on 12 May 2020).

32. Sterlitech. Defining a Pore Size and Sterile Filtering. 2014. Available online: https://www.sterlitech.com/blog/post/defining-apore-size-and-sterile-filtering-0-2-microns-vs-0-22-microns-whats-the-difference/ (accessed on 11 March 2020).

33. Bennett, A. Membrane technology: Developments in ultrafiltration technologies. Filtr. Sep. 2012, 49, 28-33. [CrossRef]

34. Madaeni, S.S.; Fane, A.G.; Grohmann, G.S. Virus removal from water and wastewater using membranes. J. Membr. Sci. 1995, 102, 65-75. [CrossRef] 